\title{
Strontium Chloride Sr-89
}

National Cancer Institute

\section{Source}

National Cancer Institute. Strontium Chloride Sr-89. NCI Thesaurus. Code C1238.

The chloride salt of a radioactive isotope of strontium. Strontium chloride $\mathrm{Sr} 89$ is taken up and incorporated preferentially in metastatic lesions in bone where it emits cytotoxic beta radiation, resulting in an inhibition and/or reduction of tumor growth and so tumorrelated bone pain. $\left(\mathrm{NClO4}_{)}\right.$ 